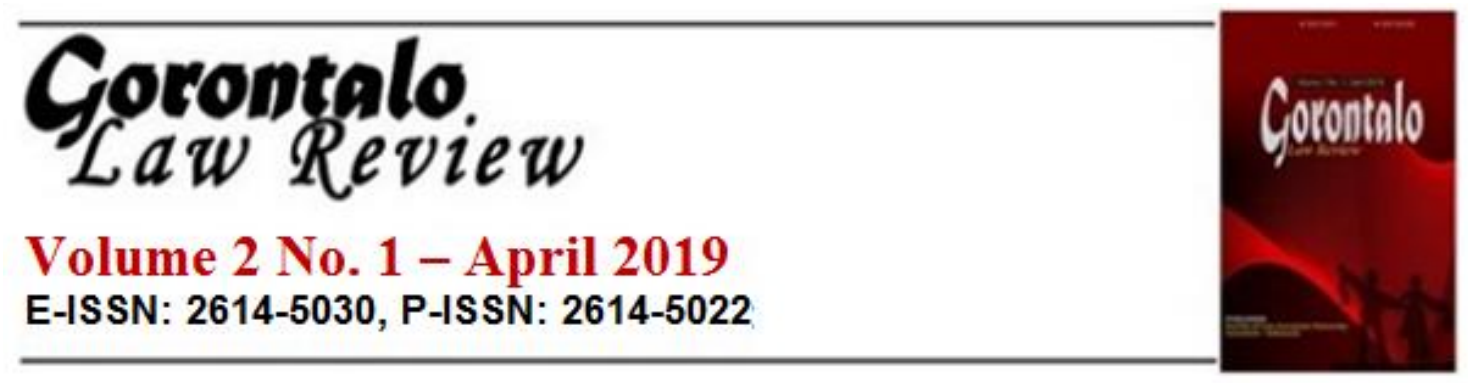

\title{
DEKRIMINALISASI TINDAK PIDANA : MEMBEDAH KEADILAN BAGI TERPIDANA DAN MANTAN TERPIDANA
}

\author{
Andi Intan Purnamasari \\ Fakultas Hukum Universitas Tadulako \\ andi.intanpurnamasari@gmail.com
}

\begin{abstract}
Abstrak
Perkembangan Hukum di Indonesia, senantiasa mengalami perubahan. Begitu juga dengan Hukum Pidana. Salah satu hal substansial yang mengalami perubahan dalam Hukum Pidana adalah terjadinya perubahan dalam Kitab Undang-undang Hukum Pidana (KUHP). Perkembangan Hukum Pidana yang terjadi memungkinkan dilakukan dekriminalisasi terhadap delik. Seperti Pasal 134,136 bis 137, 154, 155, 209,210, 387,388, 415 sampai dengan 420, 423, 425, 435 dan beberapa pasal lainnya. Sementara itu, Pasal 1 ayat (2) KUHP menyebutkan bahwa Jika sesudah perbuatan dilakukan ada perubahan dalam perundang-undangan, dipakai aturan paling ringan bagi terdakwa. Subyek Hukum Pasal 1 ayat (2) KUHP adalah terdakwa, begitu juga bila terjadi dekriminalisasi maka Subyek Dekriminalisasi adalah Terdakwa. Terjadinya dekriminalisasi terhadap delik didasarkan oleh adanya pertimbangan Filosofis, Sosiologis dan Yuridis, sehingga peraturan dapat berubah. Dengan adanya perubahan paradigma terhadap suatu delik. Maka, perubahan ini sepatutnya juga dirasakan oleh para Terpidana maupun mantan terpidana. Status terpidana dan mantan terpidana yang disandang oleh seseorang namun delik yang dilakukan tidak lagi dianggap sebagai tindak pidana, sudah tentu harus mendapat perhatian khusus. Tulisan ini mengangkat isu Keadilan bagi Terpidana dan mantan terpidana atas delik yang dilakukan bukan lagi menjadi delik hukum. Metode yang digunakan yaitu secara Normatif berdasarkan pendekatan Kepustakaan.
\end{abstract}

Kata kunci : Dekriminalisasi; Delik; Terpidana; dan Mantan Terpidana 


\begin{abstract}
Legal developments in Indonesia, always changes. As well as criminal law. One of the substantial things that changed the changes in Criminal Law was changes in the Penal Code (KUHP). The development of the Criminal Law that occurred was carried out by decriminalization of offenses. Such as Article 134.136 bis 137, 154, 155, 209.210, 387,388, 415 to 420, 423, 425, 435 and several other articles. Meanwhile, Article 1 paragraph (2) of the Criminal Code cites that if changes are made in the regulations, the lightest rule is used for the defendant. Legal Subject Article 1 paragraph (2) of the Criminal Code of the defendant, so that decriminalization can also occur, the Subject of Decriminalization is Defendant. Decriminalization occurs against offenses based on philosophical, sociological and juridical considerations so that regulations can be changed. With the paradigm change in an offense. So, this change should also be accepted by the convicts and former convicts. The status of convicts and former convicts carried by a person but the offense committed is no longer considered a criminal offense, of course, it must receive special attention. This paper raises the issue of Justice for convicts and former convicts for offenses that are no longer a legal offense. The method used by Normative about using literature.
\end{abstract}

\title{
Keywords : Decriminalization; Delict; Convicted person; and former convict.
}

\section{PENDAHULUAN}

Hukum adalah rangkaian peraturan mengenai tingkah laku individu sebagai anggota masyarakat, sedangkan satu-satunya tujuan dari hukum adalah mengadakan keselamatan, kebahagiaan dan tata tertib di dalam masyarakat. Keadaan masyarakat yang senantiasa bersifat dinamis menjadi keharusan bagi hukum untuk mengikuti perkembangan masyarakat.

Sejak dahulu hingga sekarang, para sarjana hukum saling berbeda pendapat mengenai masalah mengapa suatu kejahatan harus ditanggapi dengan suatu pidana. (Wirjono Prodjodikoro , 2003 : 14). Apa yang kini dinamakan "kejahatan" adalah pelanggaran dari norma-norma yang disebut sebagai unsur pokok kesatu dari hukum pidana. (Ibid , 2003 : 14). Pendapat mengemukakan bahwa kejahatan itu diibaratkan sebagai penghisap energi suatu bangsa. Hal ini diakibatkan karena kejahatan mengakibatkan kerugian bagi masyarakat, kelancaran produksi terganggu, perasaan orang menjadi cemas dan tidak dapat tenang bekerja dan lain sebagainya. Namun, suatu masyarakat yang kuat tentu mempunyai daya tahan yang cukup terhadap kejahatan baik itu dilakukan oleh warganya maupun oleh orang luar. Tidak ada satupun negara yang sunyi dari kejahatan, apakah itu negara sedang berkembang ataupun negara yang sudah berkembang. Namun begitu tidaklah berarti bahwa terhadap kejahatan tidak perlu dilakukan usaha-usaha penanggulangan. Salah satu cara untuk menanggulangi kejahatan ialah dengan hukum pidana. Fungsi penganggulangan kejahatan ini merupakan 
fungsi primer dari hukum pidana. Dari hukum pidana diharapkan, bahwa hukum pidana dapat melindungi masyarakat terhadap bahaya yang timbul oleh orang yang melakukan kejahatan. Dengan demikian hukum pidana harus pula sesuai dengan sifat dan corak dari kejahatan yang tentu menampakkan diri sesuai dengan perkembangan masyarakat. (Sudarto, 1983:43)

Kejahatan senantiasa berkembang sesuai dengan perkembangan zaman. bahkan perkembangan tersebut dapat dilihat bahwa tindakan yang sebelumnya bukan merupakan kejahatan kemudian menjadi kejahatan, atau suatu tindakan kejahatan yang sebelumnya ancaman pidananya rendah lalu meningkat kedua peristiwa ini disebut dengan istilah kriminalisasi. Begitu pula sebaliknya, sebuah tindakan yang sebelumnya merupakan tindak pidana kemudian mengalami perubahan menjadi tindakan yang bukan lagi sebuah tindak pidana atau dikenal dengan istilah dekriminalisasi. Perubahan kriminalisasi maupun dekriminalisasi pada sebuah delik dianggap sebagai perkembangan hukum pidana.

Dekriminalisasi merupakan sebuah pengakuan negara bahwa tindakan yang dulu dianggap sebagai delik menjadi tindakan yang bukan lagi dianggap delik. Dekriminalisasi erat kaitannya dengan strafbaar feit. Menurut Simons (Hazewinkel-Suringa, 1973:65), bahwa strafbaar feit (terhemahan harafiah : peristiwa pidana) ialah pebuatan melawan hukum yang berkaitan dengan kesalahan (schuld) seseorang yang mampu bertanggungjawab. Kesalahan yang dimaksud oleh Simons ialah kesalahan dalam arti luas yang meliputi dolus (sengaja) dan culpa late (alpa atau lalai). Dalam rumus tersebut simon memasukan unsur - unsur pebuatan pidana (criminal act) yang meliputi perbuatan dan sifat melawan hukum perbuatan dan pertanggungjawaban pidana (criminal liability) yang mencakup kesengajaan, kealpaan serta kelalaian dan kemampuan bertanggungjawab.

Van Hamel (1927:169) menguraikan strafbaar feit sebagai perbuatan manusia yang diuraikan oleh undang-undang, melawan hukum, strafwaardig (patut atau bernilai dipidana) dan dapat dicela karena kesalahan (en aan schuld te wijten). Unsur strafbaar feit menurut Van Hamel meliputi perbuatan dan perbuatan itu ditentukan oleh hukum pidana tertulis (asas legalitas). Dalam hukum pidana tertulis di Indonesia menjelaskan bila aturan hukum positif menganulir sebuah peristiwa pidana seperti beberapa pasal yang dicabut dalam KUHP dan dianggap bukan lagi peristiwa pidana maka berlakulah Pasal 1 ayat (2) KUHP.

Menarik untuk diteliti adalah kebijakan ius constitum atau ius operandum dalam hal pemberlakuan dekriminalisasi terhadap suatu delik. Pada asas yang tersirat dalam pasal 1 ayat (2) KUHP jelas diketahui bahwa bila ada perubahan peraturan perundang-undangan setelah perbuatan dilakukan, maka yang diberlakukan adalah peraturan yang menguntungkan bagi terdakwa. Namun keberadaan pasal ini tidak menjangkau bagi mereka terpidana atau mantan terpidana. Dekriminalisasi yang terjadi, menggeser kedudukan sebuah peristiwa hukum yang sebelumnya dianggap sebagai strafbaat feit menjadi peristiwa biasa seperti pada pasal 154 dan pasal 155 
KUHP. Perubahan yang terjadi inilah perlu memikirkan keadilan terhadap terpidana dan mantan terpidana terhadap delik yang mengalami dekriminalisasi.

\section{METODE PENELITIAN}

Penelitian ini menggunakan metode penelitian bersifat yuridis normatif, atau penelitian kepustakaan, yaitu jenis penelitian yang bertumpu pada sumber data sekunder sebagai data rujukan utama yang terdiri dari bahan hukum primer, bahan hukum sekunder dan bahan hukum tersier. Bahanbahan tersebut disusun secara sitematis, dikaji, kemudian ditarik suatu kesimpulan dalam hubungannya dengan masalah yang diteliti.,

\section{PEMBAHASAN}

\section{a. Keadilan Bagi Terpidana Dan Mantan Terpidana terhadap Delik Yang Telah Mengalami Dekriminalisasi}

Berdasarkan ketentuan beberapa konstitusi negara, tampak adanya pembatasan berlakunya asas legalitas dalam hal terjadinya perubahan peraturan perundang-undangan. Demikian pula dalam Kitab Undang-undang Hukum Pidana beberapa negara terdapat pembatasan terhadap asas Lex temporis delicti./ Pasal 1 ayat (2) WvS Belanda secara tegas menyatakan "Bij veraderingin de wetgeving na et tijdstip waarop het feit began is, woorden de voor den verdachte gunstigste bepaling toegepast" demikian pula Pasal 1 ayat (2) KUHP Indonesia berbunyi, 'Jika sesudah perbuatan dilakukan ada perubahan dalam perundang-undangan dipakai aturan yang paling ringan bagi terdakwa." Hal yang sama juga terdapat dalam undang-undang pidana Jerman yang dengan tegas menyatakan "Bei Verschiedenheit der Gesetze von der Zeit der begangenen Handlung bis $Z u$ deren Aburteilung ist das mildeste Gesetz anzuwneden" (Jika ada perbedaan antara ketentuan pidana yang berlaku pada waktu tindak pidana dilakukan dan ketentuan pidana yang kemudian berlaku pada waktu tindak pidana yang sama diperiksa di pengadilan, ketentuan pidana paling ringanlah yang harus ditetapkan). (Eddy O.S Hiariej, 2009:34)

Ketentuan Pasal 1 ayat (2) KUHP, menurut Utrech, ada dua pertanyaan mendasar yang harus dijawab. Pertama apa yang dimaksud dengan perubahan perundang-udangan (verandering in de wetgeving). Kedua, apa yang dimaksud dengan aturan yang paling meringankan (gunstigste bepaligen). (E.Utrecht, 1960:222). Terhadap ajaran tersebut, ada tiga ajaran yang digunakan yakni ajaran formil, ajaran materiil terbatas dan ajaran materiil tidak terbatas.

Ajaran formil dipelopori oleh Simons menyatakan bahwa "perubahan perundang-undangan" yang dimaksud dalam Pasal 1 ayat (2) dilakukan hanya jika terdapat perubahan redaksi dalam undang-undang pidana. Sedangkan ajaran materiil terbatas dianut oleh Geuns yang menyatakan bahwa makna "perubahan undang-undang" dalam pasal 1 ayat (2) adalah setiap perubahan keyakinan hukum pada pembuat undang-undang. Ajaran materiil terbatas mencakup juga perbuatan di luar undang-undang pidana yang mempengaruhi undang-undang pidana yang bersangkutan, seperti pada putusan Hoge Raad 3 Desember 1906 W.Nr. 8464 : Pada bulan Desember 1904, seorang ,mucikari mempekerjakan seorang wanita berusia 22 tahun sebagai pelacur. Perbuatan 
mucikari tersebut dituntut dengan pasal 295 ayat (1) ke-2 karena mempekerjakan wanita dibawah umur sebagai pelacur. Berdasarkan pasal 330 KUH Perdata batas usia dewasa adalah 23 tahun. Pada saat mucikari tersebut sedang diadili, pasal $330 \mathrm{KUH}$ Perdata mengalami perubahan batas usia dewasa menjadi 21 tahun. Hoge Raad membebaskan mucikari tersebut dengan alasan telah terjadi perubahan perundang-undangan sebagaimana dimaksud dalam pasal 1 ayat (2) KUHP sehingga harus diputus meringankan terdakwa. (E.Utrecht, 1960:224).

Menanggapi kasus Hoge Raad bahwa yang menerima keringanan dalam hal ini adalah terdakwa, dimana perubahan peraturan perundang-undangan terjadi saat perbuatan tersebut telah dilaksanakan dan belum memiliki putusan yang inchrah.

Ajaran materiil tidak terbatas menyatakan bahwa setiap perubahan, baik dalam keyakinan hukum pembuat undang-undang, maupun dalam keadaan karena waktu, dapat diterima sebagai perubahan perundangundangan menurut Pasal 1 ayat (2) KUHP. Komentar Utrech, ajaran materiil tidak terbatas ini adalah teori tentang waktu delik yang paling luas dan cocok dengan jiwa hukum pidana dan peradilan pidana modern yang telah menerima perluasan dengan cara analogi.

Perubahan Peraturan perundang-undangan yang mengakibatkan hadirnya dekriminalisasi terhadap tindak pidana tentu bukan hanya terjadi pada satu atau dua pasal, melainkan lebih dari beberapa pasal. Berikut beberapa kasus Tindak Pidana berdasarkan data Institute for Criminal Justice Reform (ICJR) yang tersandung kasus Penyebaran kebencian terhadap pemerintah (haatzaaiartikelen) yang tercantum dalam Pasal 154-155 KUHP :

\begin{tabular}{cl}
\hline Ko & \multicolumn{1}{c}{ Keterangan } \\
\hline Peristiwa & Mahasiswa menggalang sejumlah protes \\
Mahasiswa & yang dilakukan di berbagai kampus di \\
1978. & Indonesia mengecam kepemimpinan \\
& Presiden Soeharto dan menyatakan agar \\
& Soeharto tidak lagi menjadi Presiden RI. \\
& Akibatnya Soeharto kemudian menangkap \\
& 34 orang mahasiswa di berbagai kota di \\
& Indonesia mulai dari Jakarta, Bandung, \\
& Palembang, Surabaya, Malang, Ujung \\
& Pandang dan Yogyakarta. Rata-rata \\
& mahasiswa ini dipenjara selama 11 bulan \\
& setelah diadili dengan menggunakan pasal- \\
& pasal haatzaaiartikelen. \\
& Kasus ini sering disebut dengan insiden \\
& Bandung 5 Agustus 1989. Enam orang \\
& mahasiswa Institut Teknologi Bandung (ITB), \\
Kahus & yakni: Arnold Purba, Muh. Fadjroel Rahman, \\
ITB 1989. & Jumhur Hidayat, Enin Supriyanto, \\
\hline
\end{tabular}




\begin{tabular}{cl}
\hline & $\begin{array}{l}\text { Ammarsyah dan Bambang Sugianto } \\
\text { ditangkap dan dikenai Pasal 154, Pasal 207, } \\
\text { dan Pasal 208 KUHP. (pada kasus ini yang } \\
\text { mengalami dekriminalisasi adalah pasal 154) }\end{array}$ \\
\hline Kasus FAMI & $\begin{array}{l}\text { Pada bulan Desember tahun 1992, sejumlah } \\
\text { (Front Aksi } \\
\text { Mahasiswa }\end{array}$ \\
Indonesia) & menggelar aksi protes di gedung DPR. Saat \\
& itu, 21 mahasiwa ditangkap dan diadili \\
& untuk kasus tersebut.
\end{tabular}

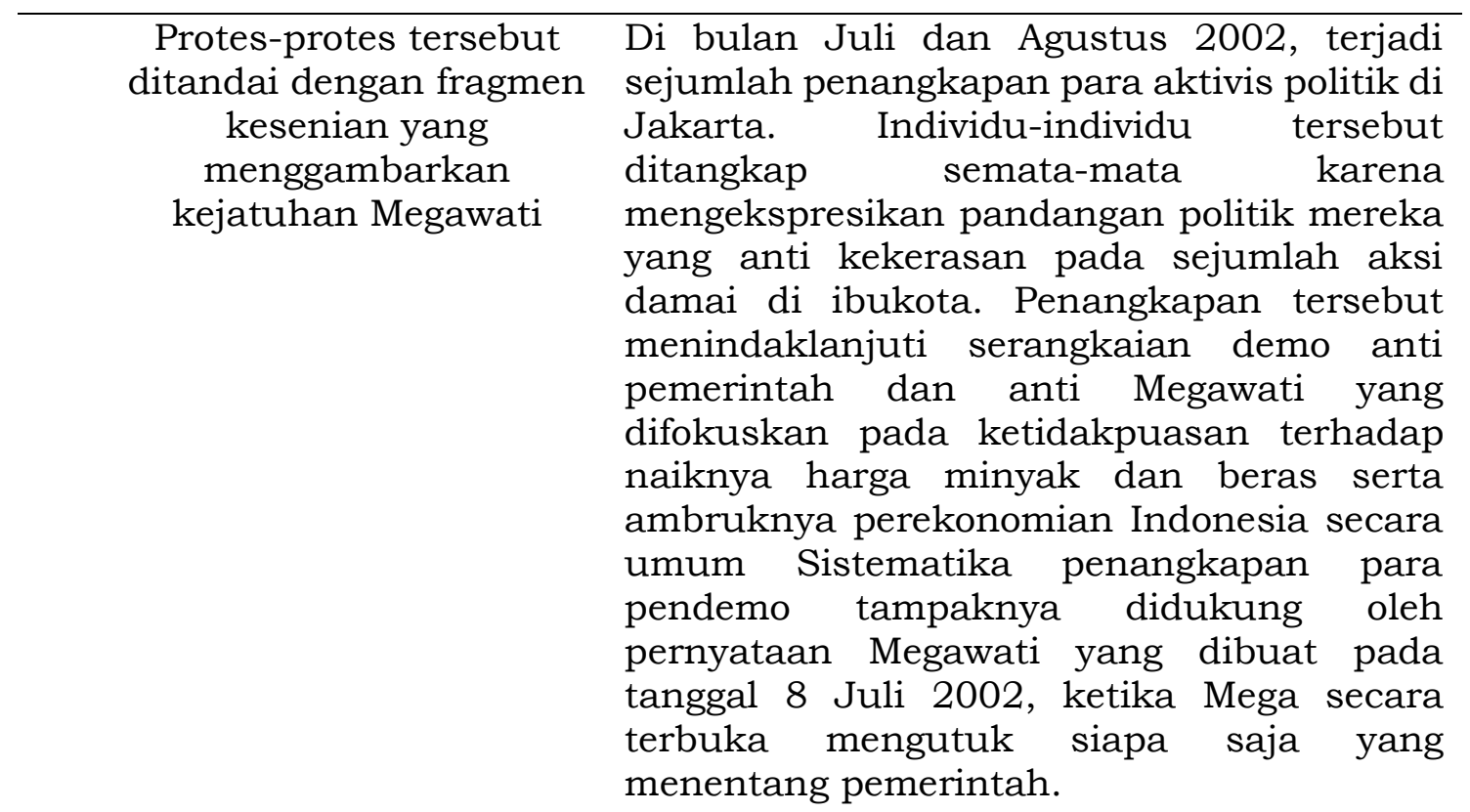

Bai Harkat Firdaus, mahasiswa Universitas

Islam Negeri Sunan Kalijaga
Di masa jabatan Presiden Susilo Bambang Yudhoyono (SBY), kebijakan penangkapan terhadap pelaku yang dituduh menghina Presiden dan Wakil Presiden berdasarkan pasal-pasal tersebut masih kerap dijalankan. Misalnya, pada tahun 2004, Bai Harkat Firdaus, mahasiswa Universitas Islam Negeri Sunan Kalijaga (2004) membakar foto Soesilo Bambang Yudhoyono dan Jusuf Kalla dalam sebuah Penyampaian Pendapat di Jakarta, dan dihukum 5 bulan penjara.

Ketua Perhimpunan Bantuan Hukum dan HAM Indonesia (PBHI) Bali dalam sebuah Penyampaian Pendapat tentang kenaikan harga BBM juga dihukum 6 bulan penjara.

Sumber : (http://icjr.or.id/data/wp-content/uploads/2016/12/TINDAKPIDANA-PENGHINAAN-Pemerintah.pdf) 
Contoh di atas adalah pasal yang mengalami dekriminalisasi. Tindakan yang dulunya dianggap sebagai tindak pidana, namun tanggal 17 Juni 2007 Mahkamah Konstitusi menyatakan Pasal 154 dan 155 Kitab Undang-undang Hukum Pidana (KUHP) bertentangan dengan UUD 1945. Perkara No. 6/PUUV/2007 diajukan Dr. R. Panji Utomo yang berprofesi sebagai dokter dan Direktur FORAK (Forum Komunikasi Antar Barak).Panji dalam permohonannya menganggap bahwa hak konstitusionalnya dirugikan dengan berlakunya Pasal 107, Pasal 154, Pasal 155, Pasal 160, Pasal 161, Pasal 207 dan Pasal 208 KUHP yang dipandang dan diyakini bertentangan dengan Pasal 27 ayat (1), Pasal 28, Pasal 28C ayat (1) dan (2), Pasal 28D ayat (1), Pasal 28E ayat (2) dan (3), Pasal 28F UUD 1945. Namun hanya Pasal 154 dan Pasal 155 KUHP yang dinyatakan oleh MK tidak mempunyai kekuatan hukum mengikat, sedangkan permohonan Pemohon selebihnya tidak dapat diterima (niet ontvankelijk verklaard). Namun begitu, kendatipun yang dianggap tidak mempunyai kekuatan mengikat hanya Pasal 154 dan 155 KUHP, sejarah membuktikan bila pasal tersebut telah menjerat beberapa orang di tahun sebelumnya seperti pada data tabel ICJR tersebut di atas.

Pertimbangan Mahkamah Konstitusi dalam Putusan Nomor 6/PUUV/2007 yakni:

Mahkamah Konstitusi, dalam pertimbangan hukumnya menjelaskan bahwa kualifikasi delik atau tindak pidana yang dirumuskan dalam Pasal 154 dan 155 KUHP adalah delik formil yang cukup hanya mempersyaratkan terpenuhinya unsur adanya perbuatan yang dilarang (strafbare handeling) tanpa mengaitkan dengan akibat dari suatu perbuatan. Akibatnya, rumusan kedua pasal pidana tersebut menimbulkan kecenderungan penyalahgunaan kekuasaan karena secara mudah dapat ditafsirkan menurut selera penguasa. Menurut Mahkamah Konstitusi, seorang warga negara yang bermaksud menyampaikan kritik atau pendapat terhadap Pemerintah, merupakan hak konstitusional yang dijamin oleh UUD 1945, akan dengan mudah dikualifikasikan oleh penguasa sebagai pernyataan "perasaan permusuhan, kebencian, atau penghinaan" terhadap Pemerintah sebagai akibat dari tidak adanya kepastian kriteria dalam rumusan Pasal 154 maupun 155 KUHP tersebut untuk membedakan kritik atau pernyataan pendapat dengan perasaan permusuhan, kebencian, ataupun penghinaan. Karena penuntut umum tidak perlu membuktikan apakah pernyataan atau pendapat yang disampaikan oleh seseorang itu benar-benar telah menimbulkan akibat berupa tersebar atau bangkitnya kebencian atau permusuhan di kalangan khalayak ramai.MK juga menjelaskan bahwa Pasal 154 dan 155 KUHP dapat dikatakan tidak rasional, karena seorang warga negara dari sebuah negara merdeka dan berdaulat tidak mungkin memusuhi negara dan pemerintahannya sendiri yang merdeka dan berdaulat, kecuali dalam hal makar. Namun, ketentuan tentang makar sudah diatur tersendiri dalam pasal lain dan bukan dalam Pasal 154 dan Pasal 155 KUHP. (Supriadi Widodo, 2016: 22)

Pertimbangan kasus hakim konstitusi di atas jelas bahwa adanya perubahan paradigma bahwa untuk menjadi negara demokrasi maka setiap 
warga negara memiliki kebebasan untuk mengungkapkan ekspersi kritikan terhadap pemerintah. Dengan dicabutnya pasal 154 dan 155 maka filosofi dari pasal tersebut yang dulunya dianggap sebagai delik justru sekarang berubah menjadi ekspesi negara berdemokrasi. Inilah yang dimaksud dalam penelitian ini bahwa perubahan peraturan perundang-undangan tentu terjadi berdasarkan pertimbangan yuridis, sosial, dan filosofis.

Pemaparan kasus di atas hanyalah sebagian kecil dari contoh delik yang mengalami perubahan. olehnya dalam sebuah pelaksanaan punishment menurut H.L Packer bahwa dalam hal phunishment kita memperlakukan seseorang karena ia telah melakukan suatu perbuatan salah dengan tujuan, baik untuk mencegah terulangnya perbuatan itu maupun untuk mengenakan penderitaan atau untuk kedua-duanya. (Muladi,Barda, 2010: 6). Pada tindakan yang bukan lagi merupakan delik, maka tujuan untuk mencegah terulangnya perbuatan itu tentulah tidak bisa terpenuhi, dimana perbuatan tersebut jika dilakukan kembali maka tidak akan berakibat tindak pidana karena telah mengalami dekriminalisasi. Bukankah hal ini patut menjadi pertimbangan bahwa untuk sebuah delik yang mengalami dekriminalisasi harus memberikan perluasan subyek yakni tidak sebatas terdakwa tetapi juga harus terpidana. Pertimbangan lain jika tujuan pidana adalah untuk memberikan penderitaan maka adilkah seseorang yang menjalani pemidanaan padahal pemidanaan tersebut jelas terhadap tindakan yang bukan lagi termasuk delik.

Keadilan yang dimaksud oleh Aristoteles bahwa keadilan secara umum erat kaitannya dengan kepatuhan terhadap hukum, lalu hukum secara pasti menyatakan bahwa adanya perubahan peraturan yang mengakibatkan terjadinya Dekriminalisasi seperti contoh kasus di atas (walaupun masih banyak kasus lain yang juga mengalami dekriminalisasi) tentu sangat bertentangan dengan rasa keadilan bagi terpidana. Keadilan secara khusus yang sifatnya disesuaikan dengan proporsi, sedangkan proporsi yang seperti bagaimana harus diberikan kepada seorang terpidana atas tindakan yang dilakukan padahal tindakan tersebut telah mengalami perubahan paradigma dan telah dinyatakan bukan lagi tindak pidana. Ini tentu menjadi pertimbangan penting bahwa hak terpidana bukan hanya sebatas mendapat hak-hak saat menjalankan masa hukumannya, namun terpidana juga berhak mendapatkan keuntungan dari perubahan peraturan.

Menurut kongres Internasional mengenai hukum pidana dan penjara tahun 1935 di Berlin, Jerman didebatkan bahwa ada atau tidaknya pengaruh suatu perubahan peraturan perundang-undangan terhadap putusan hakim yang telah memperoleh kekuatan hukum tetap (kracht van gewijsde). Terhadap pertanyaan tersebut, Pompe memberikan jawaban bahwa putusan hakim yang telah memiliki kekuatan hukum tetap hanya bisa dilawan dengan buitengewone rechtsmiddelen (alat-alat hukum yang laur biasa). Dalam hal ini, jika terjadi perubahan undang-undnag terhadap putusan hakim yang sudah memiliki kekuatan hukum tetap, maka perubahan perundang-undangan tersebut dianggap novum sebagai dasar untuk mengajukan peninjauan kembali (PK). Jika demikian halnya, maka putusan hakim yang sudah mempunyai hukum 
tetap harus disesuaikan dengan peraturan perundang-undangan baru bila hal tersebut menguntungkan terpidana.

Perubahan dan penyesuaian pemidanaan ini juga telah diatur dalam Rancangan Undang-undang Kitab Undang-undang Hukum Pidana (kemudian disingkat RUU KUHP), Pasal 58 ayat (1) RUU KUHP berbunyi bahwa Putusan pidana dan tindakan yang telah memperoleh kekuatan hukum tetap dapat dilakukan perubahan atau penyesuaian dengan mengingat perkembangan narapidana dan tujuan pemidanaan. Akan tetapi Pasal 58 RUU KUHP sebenarnya mempertimbangkan perkembangan narapidana, artinya narapidana yang berkelakuan baik serta memenuhi syarat tertentu dapat memperoleh perubahan dan penyesuaian, sesungguhnya bentuk ini mirip dengan pemberian remisi yang dikemas agak sedikit berbeda, artinya tindak pidana yang dijalani oleh narapidana masih dianggap sebagai delik, hanya saja ketentuan khususnya menjadikan seorang narapidana memperoleh perubahan dan penyesuaian. Namun konsep dalam tulisan ini adalah lebih jauh lagi melihat bahwa tujuan pemidanaan tidak dapat lagi dilakukan karena delik yang menjadikan seseorang sebagai narapidana bukan lagi dianggap sebagai delik.

Ketentuan menghilangkan pemidanaan terhadap tindak pidana yang mengalami dekriminalisasi lebih tepat dengan memberlakukan RUU KUHP dalam Pasal 3 ayat (2) berbunyi dalam hal setelah putusan pemidanaan memperoleh kekuatan hukum tetap, perbuatan yang terjadi tidak lagi merupakan tindak pidana menurut peraturan perundang-undangan yang baru, maka pelaksanaan putusan pemidanaan dihapuskan. Pemberlakuan pasal ini terhadap delik yang mengalami dekriminalisasi dianggap lebih tepat karena tujuan dari pemidanaan terhadap perbuatan yang bukan lagi tindak pidana akan menjadi hal yang tidak adil tentunya. Bagaimana mungkin seseorang dapat menjalankan hukuman, padahal tindakan yang karenanya ia dihukum tersebut bukan lagi merupakan tindak pidana.

Selain itu, imbas dari sanksi pemidanaan akan mengenai si individu sebagai pelaku, dan juga keluarga pelaku. Bahkan bilamana narapidana telah selesai menjalani masa hukumannya maka masyarakat akan tetap mengenal ia sebagai mantan narapidana. Ketika seseorang menjadi mantan narapidana beberapa kerugian yang ia dapatkan, salah satunya yaitu kesulitan-kesulitan secara administrasi akan dialami, misalnya beberapa ketentuan administrasi untuk pekerjaan yang mengharuskan seseorang melengkapi persyaratan berkelakuan baik. Namun bagi seorang mantan terpidana, tentu hal ini sulit didapatkan, mengingat rekam jejak tindak pidana yang dilakukan. Hal ini bukan hanya berlaku bagi delik yang masih menjadi tindak pidana, untuk delik yang dianggap bukan lagi tindak pidana, pelabelan pada mantan terpidana masih terjadi. Padahal delik yang menyebabkan ia menjadi terpidana dan menjadi mantan terpidana telah mengalami dekriminalisasi. RUU KUHP pun hanya mengatur tentang perubahan pemidanaan bagi narapidana. Seperti dijelaskan dalam Pasal 3 sebelumnya bahwa narapidana akan mendapatkan hak pembebasan bilamana tindak pidana yang dia lakukan telah mengalami dekriminalisasi. Belum ada satu pun aturan dalam RUU KUHP yang menegaskan tentang tanggung jawab negara terhadap mantan narapidana atas 
delik yang ia jalani dan telah mengalami dekriminalisasi. Olehnya patut pula seorang mantan terpidana mendapatkan pembersihan nama baik terhadap delik yang ia lakukan dan telah mengalami dekriminalisasi. Pembersihan nama baik yang ia dapatkan tentu akan berdampak pada diri mantan terpidana tersebut dan juga terhadap keluarga mantan terpidana yang terlanjur mendapatkan pelabelan oleh masyarakat.

\section{KESIMPULAN}

1) Dekriminalisasi terjadi karena adanya perubahan paradigma terhadap sebuah delik. Dimana, delik yang dulunya dianggap sebagai tindak pidana menjadi bukan lagi tindak pidana, bahkan pengaturan dekriminalisasi hanya tersirat disebutkan dalam Pasal 1 ayat (2) KUHP. Dekriminalisasi tidak cukup hanya mempertimbangkan keberadaan terdakwa, namun juga harus mempertimbangkan keberadaan terpidana dan mantan terpidana.

2) Subjek Dekriminalisasi dalam Pasal 1 ayat (2) KUHP adalah terdakwa, bukan terpidana maupun mantan terpidana. Peraturan ini perlu diubah sebab perubahan paradigma sebuah delik menjadi bukan delik artinya tidak ada pertanggungjawaban pidana yang harus dipertanggungjawabkan, dimana tidak ada unsur kesalahan yang harus di pertanggungjawabkan oleh terpidana.

3) RUU KUHP Pasal 3 telah menegaskan pembebasan bagi narapidana yang menjalani hukuman bagi delik yang telah dinyatakan bukan lagi tindak pidana. Ketentuan ini dianggap lebih memenuhi unsur keadilan.

4) Bilamana negara belum memberlakukan RUU KUHP, maka untuk mengakomodir hak narapidana maka sebaiknya memberlakukan perubahan peraturan (dekriminalisasi) sebagai novum, sehingga terpidana dapat mengambil langkah untuk melakukan Peninjauan Kembali atas sanksi delik sedang ia jalani.

5) Penambahan hak akibat dekriminalisasi bukan hanya dirasakan oleh terdakwa dan terpidana, harus juga dirasakan oleh mantan terpidana. Hal ini berkaitan erat dengan pembersihan nama baik yang mana seseorang akan selalu dilabelkan sebagai seorang mantan terpidana padahal delik yang dilakukan bukan lagi tindak pidana, tentu ini bertentangan dengan teori keadilan.

\section{DAFTAR PUSTAKA}

\section{a. Buku}

Adam Chazawi, 2007, Pelajaran Hukum Pidana Bagian I, PT Raja Grafindo Persada, Jakarta.

Barda Nawawi Arief, 2012, Kebijakan Formulasi Ketentuan Pidana Dalam Peraturan Perundang-Undangan, Pustaka Magister, Semarang.

Damanhuri Fattah, "Teori Keadilan Menurut John Rawls", Jurnal TAPIs, Vol.9 No.2 Juli-Desember 2013,

Eddy O.S Hiariej, 2009, Asas Legalitas \& Penemuan Hukum dalam Hukum Pidana, Erlangga, Jakarta.

E.Utrecht, 1960, Hukum Pidana I, Penerbitan Universitas, Bandung.

Muladi dan Barda Nawawi Arief, 2010, Teori - teori dan Kebijakan Pidana, Alumni, Bandung. 
Moeljatno,S.H., 2015, Asas-asas Hukum Pidana, Rineka Cipta, Jakarta.

Sudarto, 1983, Hukum Pidana dan Perkembangan Masyarakata, Sinar Baru, Bandung.

Soerjono Soekanto, 2006, Perbandingan Hukum, Citra Adiya Bakti , Bandung. Soekanto Soerjono dan Mamudji Sri, 1990, Penelitian Hukum Normatif Suatu Tinjaun Singkat, Rajawali Press, Jakarta.

Wirjono Prodjodikoro, 2003, Asas-asas Hukum Pidana di Indonesia, Refika Aditama, Bandung.

Zainal Abidin Farid, 2010, Hukum Pidana I, Sinar Grafika, Jakarta. HazewinkelSuringa,Mr.D, 1953, Inleiding Tot De Studie van het Nederlandse Strafrecht. Bewerkt door Mr.J Remmelink. Zesde druk. H.D. Tjeenk Willink BV. Groningen 1973.

\section{b. Undang Undang}

Kitab Undang-undang Hukum Pidana (KUHP)

Rancangan Undang-undang Kitab Undang-undang Hukum Pidana (RUU KUHP).

c. Sumber Online

http:/ /icjr.or.id/data/wp-content/uploads/2016/12/TINDAK-PIDANA-

PENGHINAAN-Pemerintah.pdf diakses 14 Februari 2019 